\title{
Respons Mahasiswa terhadap Pembelajaran Berbasis Guided Discovery pada Mata Kuliah Anatomi dan Fisiologi Makhluk Hidup
}

\author{
Aida Fikriyah \\ Program Studi Pendidikan Sains, Fakultas Ilmu Pendidikan, Universitas Trunojoyo Madura. \\ Jalan Raya Telang PO BOX 2 Kamal, Bangkalan - Madura, Indonesia \\ E-mail: aida.fikriyah@trunojoyo.ac.id
}

\begin{abstract}
Abstrak
Penelitian ini bertujuan untuk mendeskripsikan respons mahasiswa terhadap pembelajaran berbasis Guided discovery pada mata kuliah Anatomi dan Fisiologi Makhluk Hidup. Penelitian ini merupakan penelitian deskriptif kualitatif kuantitatif dengan sasaran sebanyak 46 mahasiswa Program Studi Pendidikan IPA semester IV tahun akademik 2018/2019 yang dilaksanakan pada perkuliahan Anatomi dan Fisiologi Makhluk Hidup. Hasil penelitian menunjukkan bahwa mahasiswa memberikan respons positif terhadap pembelajaran yang telah dilakukan. Berdasarkan hal tersebut, dapat disimpulkan bahwa respons mahasiswa terhadap pembelajaran berbasis Guided discovery pada mata kuliah Anatomi dan Fisiologi Makhluk Hidup termasuk dalam kategori kuat.
\end{abstract}

Kata Kunci: aktivitas, respons, guided discovery

\begin{abstract}
This research aimed at describing the students' response toward Guided discovery learning in Anatomy and Physiology of Organisms lecture. It included a quantitative-qualitative descriptive study which involved 46 students of Science Education Department on the $4^{\text {th }}$ semester, in the academic year of 2018/2019 as the subjects. Findings obtained in this study indicated that students showed positive response toward the learning process. To conclude, the students' response toward Guided discovery learning in Anatomy and Physiology of Organisms lecture can be categorized as strong criteria.
\end{abstract}

Keywords: Activity, response, guided discovery

\section{PENDAHULUAN}

Kegiatan pembelajaran adalah kegiatan yang berkaitan dengan cara pengajar menyampaikan materi kepada anak didik dan kegiatan pebelajar dalam mempelajari materi yang disampaikan oleh pengajar (Sudjana dan Rivai, 2002). Menurut BSNP (2006), pembelajaran merupakan usaha yang disengaja, terarah, dan bertujuan agar orang lain dapat memperoleh pengalaman yang bermakna. Kegiatan pembelajaran diharapkan dapat memberikan suasana yang menyenangkan bagi mahasiswa sehingga mahasiswa dapat dengan mudah memahami materi yang diajarkan. Maka dari itu, setiap pengajar harus memahami proses belajar mahasiswa dengan sebaik-baiknya agar dapat memberikan arahan dan bimbingan belajar serta dapat menyediakan lingkungan belajar yang tepat dan sesuai keinginan mahasiswa (Arsyad, 2009).

Pembelajaran sains dapat menjadi sarana bagi mahasiswa untuk mempelajari alam dan makhluk hidup serta interaksinya. Sajidan (2013) menyatakan bahwa sains pada hakekatnya adalah kumpulan pengetahuan, cara berpikir, dan penyelidikan. Kumpulan pengetahuan dapat berupa fakta, konsep, prinsip, hukum, teori, dan model. Sains sebagai cara berpikir adalah kegiatan berpikir akibat dari adanya rasa ingin tahu untuk memahami fenomena alam. Sedangkan sains sebagai cara penyelidikan merupakan cara bagaimana informasi ilmiah diperoleh, diuji, dan divalidasikan.

Sains atau IPA dapat dikatakan sebagai body of knowledge, karena sains mengandung berbagai fakta dari hasil kegiatan berbasis metode ilmiah yang menjelaskan apa, mengapa, dan bagaimana suatu fenomena atau 
gejal alam dapat terjadi. Pengetahuan sendiri terdiri atas konsep, prinsip, fakta, hukum, dan teori tentang suatu gejala atau fenomena (Ali, 2013).

Scaria et al. (2013) mengungkapkan bahwa sains memiliki kekhasan dan keunikan dibandingkan dengan ilmu-ilmu yang lain karena merupakan salah satu ilmu pengetahuan yang mempelajari makhluk hidup dan kehidupannya dari berbagai aspek persoalan dan tingkat organisasinya serta interaksi antar satu organisme dengan organisme lain dan juga dengan lingkungannya yang dikaitkan dengan aspek fisik dan kimiawi. Adapun produk keilmuan sains berwujud kumpulan fakta-fakta maupun konsep-konsep sebagai hasil dari proses keilmuan sains.

Ilmu sains memiliki peran sebagai alat untuk mencapai tujuan pembelajaran yaitu suatu proses untuk mengantarkan pebelajar dalam mencapai tujuan belajarnya. Sains juga mengajarkan mahasiswa untuk belajar menggunakan metode ilmiah, meliputi merumuskan masalah, melakukan observasi, orientasi lapangan dan literatur, membuat hipotesis dan anggapan dasar, mengumpulkan data, dan menarik kesimpulan (Sajidan, 2013).

Mahasiswa yang belajar menggunakan metode ilmiah diharapkan dapat memiliki ilmu pengetahuan yang sesuai dengan perkembangan sains dan teknologi dan sikapsikap ilmiah seperti jujur, terbuka, rasa ingin tahu, teliti, cermat, dan akurat yang merupakan bagian dari nilai kehidupan (Sumintono, 2010). Widhy (2013) juga mengungkapkan bahwa mahasiswa yang berkarakter dapat dicirikan apabila mahasiswa memiliki kemampuan mengintegrasikan pengetahuan, keterampilan, dan sikap dalam usaha untuk memahami lingkungan.

Pembelajaran sains sebaiknya berorientasi pada empat hal yaitu produk, proses atau metode, sikap, dan teknologi. Hutami \& Wiyatno (2018) menyatakan bahwa empat komponen tersebut diharapkan dapat diterapkan dalam pembelajaran dengan saling berkesinambungan agar mahasiswa mampu belajar secara efektif.

Pembelajaran sains sebaiknya dilaksanakan dengan tujuan mampu mengembangkan kemampuan mahasiswa dalam memahami komponen kehidupan di bumi dan mendorong mahasiswa untuk menjaga dan memanfaatkannya secara bijaksana. Pembelajaran sains juga dapat meningkatkan minat mahasiswa dalam menemukan tantangan, mengambil resiko, dan belajar dari kesalahan karena mahasiswa melaksanakan proses ilmiah dalam pembelajaran sains.

Pendekatan ilmiah juga merupakan bagian yang penting dari pembelajaran karena pembelajaran merupakan proses ilmiah yang dapat menghasilkan perubahan pada aspek pengetahuan, perilaku, dan pribadi yang bersifat permanen. Perubahan tersebut dapat bersifat penambahan atau pengayaan pengetahuan, perilaku, atau kepribadian, dapat pula bersifat pengurangan atau reduksi pengetahuan, perilaku, atau kepribadian yang tidak dikehendaki (Riyanto, 2009).

Pembelajaran dengan pendekatan ilmiah juga bertujuan agar mahasiswa mampu membangun konsep, hukum, atau prinsip melalui kegiatan mengamati untuk mengindentifikasi hal-hal yang ingin diketahui, merumuskan pertanyaan dan merumuskan hipotesis, mengumpulkan data dengan berbagai teknik, menganalisis/mengolah data dan menarik kesimpulan serta mengkomunikasikan kesimpulan untuk memperoleh pengetahuan, keterampilan dan sikap. Langkah-langkah tersebut dapat dilanjutkan dengan kegiatan mencipta (Suyono, 2009).

Nasution (2013) memandang bahwa pendekatan ilmiah paling cocok dalam pengembangan sikap, keterampilan, dan pengetahuan. Para ilmuwan dalam melaksanakan kerja ilmiah lebih mengedepankan penalaran induktif (inductive reasoning) dibanding penalaran deduktif (deductive reasoning). Penalaran deduktif dilakukan dengan mengamati fenomena umum untuk menarik kesimpulan yang spesifik. Sebaliknya, penalaran induktif dilakukan dengan mengamati fenomena atau situasi spesifik untuk menarik kesimpulan secara keseluruhan.

Nasution (2013) mengungkapkan bahwa pembelajaran menggunakan pendekatan ilmiah dipandang mampu mengantarkan mahasiswa mencapai keterampilan berpikir, merasa, dan melakukan. Sajidan (2013) juga melaporkan bahwa pembelajaran berbasis pendekatan ilmiah mampu meningkatkan kualitas pembelajaran, yang ditunjukkan dengan ketuntasan hasil belajar kompetensi pengetahuan sebesar $90,6 \%$ dan kompetensi keterampilan sebesar $83,8 \%$.

Berdasarkan hasil observasi pada mahasiswa Program Studi Pendidikan IPA Universitas Trunojoyo Madura, sebagian besar mahasiswa masih memiliki penguasaan konsep 
dan keterampilan pemecahan masalah yang rendah. Selain itu, pembelajaran pada mata kuliah Anatomi dan Fisologi Makhluk Hidup berisi berbagai konsep dan istilah dalam sains yang membutuhkan penguatan lebih matang.

Pembelajaran berbasis Guided discovery merupakan salah satu pembelajaran sains yang menerapkan metode ilmiah dan melibatkan unsur sains berupa pengetahuan dari berbagai sumber belajar, teknologi berupa aplikasi dari ilmu pengetahuan yang bertujuan untuk memudahkan pengambilan keputusan saat berada di lingkungan masyarakat yang ada di sekitar kita. Mansour (2012) menyatakan bahwa pembelajaran ini memungkinkan mahasiswa untuk memahami konsep dan proses sains yang berhubungan dengan kehidupan nyata. Pembelajaran ini dapat menggabungkan pengetahuan, kemampuan, sikap, dan nilai-nilai penting dalam kehidupan.

Pembelajaran berbasis Guided discovery dapat didefinisikan sebagai pembelajaran penemuan terbimbing yang menciptakan situasi belajar yang mampu melibatkan pebelajar untuk belajar secara aktif dan mandiri dalam menemukan suatu konsep atau teori, pemahaman, dan pemecahan masalah. Adapun proses pembelajaran yang memfokuskan pada kegiatan penemuan membutuhkan pengajar sebagai fasilitator dan pembimbing (Destrini dkk., 2018).

Pardede dkk. (2016) melaporkan bahwa model Guided discovery mampu membangkitkan motivasi belajar. Selain itu, Ali (2013) juga telah membuktikan bahwa pembelajaran dengan model ini mampu meningkatkan kemampuan memecahkan masalah pada pebelajar. Pembelajaran Guided discovery mampu memberikan kesempatan pada mahasiswa untuk menemukan fakta dan konsep terkait sains secara mandiri (Gholamian, 2013).

Pembelajaran berbasis Guided discovery mengharuskan mahasiswa menggunakan informasi untuk mengkonstruksi pemahamannya sendiri sehingga pemahaman materi lebih berbekas dalam diri mahasiswa. Model Guided Discovery Learning atau pembelajaran penemuan terbimbing merupakan model pembelajaran yang menciptakan suasana belajar yang mampu melibatkan mahasiswa untuk belajar secara aktif dan mandiri dalam menemukan suatu konsep atau teori, pemahaman, dan pemecahan masalah. Proses penemuan tersebut membutuhkan pengajar sebagai fasilitator dan pembimbing. Adapun banyaknya bantuan yang diberikan oleh pengajar tidak mempengaruhi mahasiswa untuk melakukan penemuan sendiri.

Model pembelajaran Guided discovery telah terbukti mampu membimbing mahasiswa untuk meningkatkan keterampilan dan proses kognitif, menguatkan kognitif, meningkatkan kemampuan pemecahan masalah, memperkuat konsep, mendorong keterlibatan mahasiswa, dan melatih mahasiswa dalam belajar aktif dan mandiri. Dikarenakan pembelajaran tesebut mampu memfasilitasi pebelajar untuk dapat belajar secara mandiri dan aktif, maka perlu dilaksanakan pembelajaran berbasis Guided discovery pada mata kuliah Anatomi dan Fisiologi Makhluk Hidup.

Penelitian ini bertujuan untuk mendeskripsikan respons mahasiswa terhadap pembelajaran berbasis Guided discovery pada mata kuliah Anatomi dan Fisiologi Makhluk Hidup.

\section{METODE}

Penelitian ini merupakan penelitian deskriptif kualitatif kuantitatif, Sasaran penelitian ini adalah 46 mahasiswa Program Studi Pendidikan IPA semester IV tahun akademik 2018/2019. Pembelajaran Guided discovery dilaksanakan pada materi sistem pencernaan dalam perkuliahan Anatomi dan Fisiologi Makhluk Hidup. Penelitian ini dilaksanakan pada bulan Mei 2019 pada Program Studi Pendidikan IPA Universitas Trunojoyo Madura.

Pembelajaran Guided discovery terdiri atas beberapa tahapan, yaitu: 1) pemberian stimulus, 2) problem statement, 3) data collecting, 4) data processing, 5) verifikasi data, dan 6) generalisasi. Pembelajaran ini memfokuskan pada pengayaan konsep dan pemberian permasalahan terkait materi sistem pencernaan manusia.

Tahap pertama yaitu stimulus, mahasiswa diberikan pertanyaan atau menganjurkan mahasiswa untuk mengamati gambar maupun membaca buku mengenai materi sistem pencernaan.

Selanjutnya, tahap kedua yaitu Problem statement dilaksanakan dengan memberikan kesempatan kepada mahasiswa untuk mengidentifikasi sebanyak mungkin masalah yang relevan dengan bahan pelajaran, kemudian memilih dan merumuskannya dalam bentuk hipotesis. 
Tahapan ketiga yaitu Data collection, yaitu memberikan kesempatan kepada mahasiswa untuk mengumpulkan informasi terkait materi sistem pencernaan. Tahapan keempat yaitu Data processing, yaitu mahasiswa dibimbing untuk mengolah data yang telah diperoleh oleh mahasiswa.

Selanjutnya, tahapan Verifikasi dilaksanakan dengan meminta mahasiswa untuk mengadakan pemeriksaan secara cermat untuk membuktikan benar tidaknya hipotesis yang telah dirumuskan. Tahapan terakhir adalah Generalisasi, yaitu kegiatan dimana mahasiswa dibimbing untuk melakukan penarikan kesimpulan.

Data respons mahasiswa diperoleh dari instrumen lembar angket respons yang berisi tujuh pertanyaan. Hasil respons mahasiswa diukur menggunakan skala Guttman, yaitu skala yang digunakan untuk jawaban yang bersifat tegas dan konsisten, berupa skor tertinggi yang bernilai 1 untuk jawaban "ya" dan skor terrendah yang bernilai 0 untuk jawaban "tidak". Persentase respons mahasiswa dihitung menggunakan rumus berikut:

Respons mahasiswa (\%) $=\frac{\sum \mathrm{K}}{\sum \mathrm{N}} \times 100 \%$ (1)

Keterangan:

$\sum K=$ Jumlah mahasiswa yang memberikan jawaban "Ya".

$\sum N=$ Jumlah mahasiswa yang mengisi lembar angket respons mahasiswa.

Selanjutnya, persentase respons mahasiswa yang diperoleh dapat disimpulkan dengan kriteria sebagai berikut:

Tabel 1. Kriteria penilaian respons mahasiswa

\begin{tabular}{lcc}
\hline No & Persentase & Kategori \\
\hline 1. & $0-20 \%$ & $\begin{array}{c}\text { Sangat } \\
\text { lemah }\end{array}$ \\
2. & $21-40 \%$ & Lemah \\
3. & $41-60 \%$ & Cukup \\
4. & $61-80 \%$ & Kuat \\
5. & $81-100 \%$ & Sangat kuat \\
\hline
\end{tabular}

\section{HASIL DAN PEMBAHASAN}

Hasil respons mahasiswa terhadap pembelajaran berbasis Guided discovery pada mata kuliah Anatomi dan Fisiologi Makhluk Hidup disajikan pada Tabel 2.

Tabel 2. Hasil respons mahasiswa

\begin{tabular}{|c|c|c|c|}
\hline No & Pertanyaan & $\begin{array}{c}\text { Persentase } \\
\text { Ya }(\%)\end{array}$ & $\begin{array}{c}\text { Kateg } \\
\text { ori }\end{array}$ \\
\hline 1. & $\begin{array}{l}\text { Apakah pembelajaran } \\
\text { GD menyenangkan? }\end{array}$ & 78 & Kuat \\
\hline 2. & $\begin{array}{l}\text { Apakah pembelajaran } \\
\text { GD mudah diikuti? }\end{array}$ & 76 & Kuat \\
\hline 3. & $\begin{array}{l}\text { Apakah materi yang } \\
\text { telah dipelajari } \\
\text { dengan pembelajaran } \\
\text { GD mudah difahami? }\end{array}$ & 65 & Kuat \\
\hline 4. & $\begin{array}{l}\text { Apakah pengajar } \\
\text { membimbing selama } \\
\text { pembelajaran GD? }\end{array}$ & 74 & Kuat \\
\hline 5. & $\begin{array}{l}\text { Apakah pembelajaran } \\
\text { GD baru bagimu? }\end{array}$ & 67 & Kuat \\
\hline 6. & $\begin{array}{l}\text { Apakah kegiatan } \\
\text { pembelajaran tersebut } \\
\text { dapat meningkatkan } \\
\text { motivasi belajar } \\
\text { kamu? }\end{array}$ & 83 & $\begin{array}{c}\text { Sangat } \\
\text { kuat }\end{array}$ \\
\hline 7. & $\begin{array}{l}\text { Apakah kamu setuju } \\
\text { jika semua topik } \\
\text { diajarkan } \\
\text { menggunakan model } \\
\text { pembelajaran ini? }\end{array}$ & 83 & $\begin{array}{c}\text { Sangat } \\
\text { kuat }\end{array}$ \\
\hline & $\begin{array}{l}\text { sentase total respons } \\
\text { mahasiswa }(\%)\end{array}$ & 75 & Kuat \\
\hline
\end{tabular}

Berdasarkan data pada Tabel 2 dapat dilihat bahwa respons mahasiswa terhadap pembelajaran Guided discovery pada mata kuliah Anatomi dan Fisiologi Makhluk Hidup adalah sebesar $75 \%$ dengan kategori kuat.

Ali (2013) menyatakan bahwa pembelajaran berbasis Guided discovery terbukti efektif digunakan dalam pembelajaran karena memuat dua kriteria penting dalam pembelajaran aktif. Dua kriteria tersebut adalah membangun pengetahuan untuk membentuk pemahaman tentang informasi baru dan mengintegrasikan pengetahuan baru dengan pengetahuan awal mahasiswa sehingga terbentuk pengetahuan yang tepat (Destrini dkk., 2018).

Pembelajaran Guided discovery juga terbukti menyenangkan dilihat dari respons positif mahasiswa. Slavin (2009) menyatakan bahwa situasi belajar harus menyenangkan karena semakin menyenangkan dalam belajar, maka semakin banyak konsep materi yang dapat dipahami oleh mahasiswa.

Selanjutnya, berdasarkan data tersebut dapat dikatakan bahwa metode penemuan adalah suatu kegiatan belajar yang dirancang sedemikian sehingga mahasiswa dapat menemukan konsep atau prinsip melalui proses mental yang dilaluinya sendiri (Rachayuni, 2016). Selain itu, menurut Taufik (2012) proses mental yang dialami oleh pebelajar 
selama memahami suatu materi dapat berupa mengamati, menggolongkan, membuat dugaan, menjelaskan, mengukur, membuat kesimpulan, dan sebagainya.

Model pembelajaran Guided discovery telah terbukti mampu membimbing mahasiswa untuk meningkatkan keterampilan dan proses kognitif, menguatkan kognitif, meningkatkan kemampuan pemecahan masalah, memperkuat konsep, mendorong keterlibatan mahasiswa, dan melatih mahasiswa dalam belajar aktif dan mandiri. Hal ini sejalan dengan penelitian yang telah dilakukan oleh Yusniawati dkk. (2015) yang juga telah membuktikan bahwa pembelajaran Guided discovery mampu meningkatkan hasil belajar, aktivitas, dan respons pebelajar.

Adapun Slavin (2009) menyatakan bahwa proses belajar dengan metode penemuan memberikan kesempatan secara luas kepada mahasiswa untuk mendapatkan pengalaman. Melalui pengalaman belajar dengan pengamatan langsung, mahasiswa akan lebih termotivasi untuk belajar.

Hasil belajar dengan memberikan pengalaman berupa pengamatan langsung akan membuat materi ajar akan bertahan lebih lama pada memori mahasiswa (Shieh \& Lean, 2016) Senada dengan teori Bruner mengungkapkan bahwa pembelajaran dengan penemuan terbimbing sukses meningkatkan pemahaman konsep tentang sains. Hasil penelitian tersebut dapat membuktikan bahwa pembelajaran dengan penemuan terbimbing dapat menigkatkan pemahaman konsep sehingga meningkatkan hasil belajar mahasiswa.

Sejalan dengan Hosna (2014) yang memaparkan kelebihan dari model Guided Discovery Learning adalah sebagai berikut: 1) Membantu mahasiswa untuk memperbaiki dan meningkatkan keterampilan-keterampilan dan proses-proses kognitif, 2) Pengetahuan yang diperoleh melalui model ini sangat pribadi dan ampuh karena menguatkan pengertian, ingatan, dan transfer, 3) Mampu meningkatkan kemampuan mahasiswa untuk memecahkan masalah, 4)) Membimbing mahasiswa memperkuat konsep dirinya, karena memperoleh kepercayaan bekerja sama dengan yang lain, 5) Mendorong keterlibatan keaktifan mahasiswa, 6) Mendorong mahasiswa berpikir intuisi dan merumuskan hipotesis sendiri, 7) Melatih mahasiswa belajar mandiri, dan 8) Mahasiswa mampu secara aktif terlibat dalam kegiatan belajar mengajar, karena mahasiswa berpikir dan menggunakan kemampuan untuk menemukan hasil akhir.

Model Guided Discovery Learning menganut pandangan konstruktivisme yang menekankan pemahaman konsep belajar melalui peran aktif mahasiswa (Hamalik, 2003). Dalam pembelajaran ini, pengajar merancang kegiatan yang dapat mengakomodasi mahasiswa melakukan penemuan menggunakan proses mental untuk menemukan konsep atau prinsip. Kegiatan proses mental meliputi mengamati, menggolongkan, mengukur, menduga, menganalisis, dan menyimpulkan (Sardiman, 2007).

Proses penemuan menggunakan bimbingan lebih menguntungkan dikarenakan mampu meningkatkan penemuan konsep pada mahasiswa daripada penemuan murni (Alfieri, Patricia, \& Naomi, 2011). Adapun bimbingan dari pengajar bertujuan untuk membantu mahasiswa dalam memahami tujuan dan prosedur kegiatan pembelajaran (Ratumanan, 2009).

Tanggapan dan ketertarikan mahasiswa terhadap pembelajaran Guided Discovery yang telah dilaksanakan karena mahasiswa mampu berperan secara aktif, sehingga tidak merasa bosan dan jenuh selama proses pembelajaran. Suasana yang menyenangkan membuat mahasiswa dapat menikmati pembelajaran, sehingga hasil belajar juga dapat mengalami peningkatan (Kertamuda, 2008).

Selain itu, partisipasi aktif dari mahasiswa dalam mengajukan dan menjawab pertanyaan, mendiskusikan, dan menyimpulkan dapat membuat belajar menjadi bermakna, sehingga mahasiswa dapat mengontruksi konsepnya sendiri yang dapat meningkatkan hasil belajar ranah pengetahuan.

Pembelajaran berbasis Guided discovery merupakan salah satu pembelajaran yang menerapkan metode ilmiah dan melibatkan unsur sains berupa pengetahuan dari berbagai sumber belajar, teknologi berupa aplikasi dari ilmu pengetahuan yang bertujuan untuk memudahkan pengambilan keputusan saat berada di lingkungan masyarakat yang ada di sekitar kita. Mansour (2012) menyatakan bahwa pembelajaran ini memungkinkan mahasiswa untuk memahami konsep dan proses sains yang berhubungan dengan kehidupan nyata. Pembelajaran ini dapat menggabungkan pengetahuan, kemampuan, sikap, dan nilai-nilai penting dalam kehidupan. 
Pembelajaran berbasis Guided discovery dapat didefinisikan sebagai pembelajaran penemuan terbimbing yang menciptakan situasi belajar yang mampu melibatkan pebelajar untuk belajar secara aktif dan mandiri dalam menemukan suatu konsep atau teori, pemahaman, dan pemecahan masalah. Adapun proses pembelajaran yang memfokuskan pada kegiatan penemuan membutuhkan pengajar sebagai fasilitator dan pembimbing (Destrini dkk., 2018).

Proses pembelajaran dikatakan berhasil tidak terlepas dari kemampuan pengajar dalam menerapkan model pembelajaran yang mampu melibatkan mahasiswa secara aktif. Penerapan model pembelajaran yang tepat dapat menciptakan kondisi pembelajaran yang menyenangkan untuk mendorong mahasiswa belajar secara aktif (Aunurrahman, 2009). Suasana belajar yang tidak membosankan juga terbukti dapat meningkatkan hasil belajar (Mulyani, 2000). Pernyataan Aunurrahman dan Mulyani sejalan dengan hasil penelitian yang menunjukan adanya respons mahasiswa yang positif terhadap pembelajaran yang telah dilaksanakan, sehingga dapat disimpulkan bahwa penerapan Guided Discovery Learning merupakan model yang tepat untuk mendorong mahasiswa untuk belajar aktif.

Fahrudin (2010) juga menjelaskan bahwa pengajar yang tidak dapat menerapkan model pembelajaran tertentu dapat mengakibatkan hasil belajar anak didik menjadi rendah. Pembelajaran Guided discovery telah terbukti mampu meningkatkan minat belajar mahasiswa yang dapat dilihat dari hasil respons mahasiswa yang positif dan termasuk ke dalam kategori kuat.

Dalam pembelajaran Guided discovery juga telah terbukti bahwa mahasiswa mampu melatih sikap self-awareness. Mendatu (2010) mengemukakan Self-Awareness adalah keadaan dimana seseorang bisa memahaminya dirinya sendiri dengan setepat-tepatnya. seseorang disebut memiliki Self-Awareness jika seseorang tersebut memahami emosi dan mood yang sedang dirasakan, kritis terhadap informasi mengenai dirinya sendiri, dan sadar tentang dirinya yang nyata.

Adapun indikator kemampuan SelfAwareness adalah: 1) Adanya pengetahuan yang dalam dan akurat mengenai diri dan emosi diri, 2) Adanya pemahaman dan peramalan mengenai reaksi emosi diri terhadap situasi, 3) Benar-benar mengetahui nilai-nilai dan keyakinan inti diri sendiri serta mengetahui dampak dan efek yang membahayakan dari nilai dan keyakinan.

Dari uraian di atas dapat disimpulkan bahwa kemampuan Self-Awareness adalah wawasan mengenai diri sendiri atau wawasan mengenai alasan-alasan dari tingkah laku sendiri, pemahaman diri sendiri. Pada proses pembelajaran Guided discovery, mahasiswa mampu melatihkan keterampilan dan sikap ilmiah, salah satunya adalah keterampilan berpikir tingkat tinggi dan kemampuan selfawareness.

Pada pembelajaran Guided dsicovery juga dapat dinyatakan bahwa mahasiswa belajar dengan pendekatan ilmiah sehingga sikap ilmiah mahasiswa juga dapat terlatihkan. Nasution (2013) memandang bahwa pendekatan ilmiah paling cocok dalam pengembangan sikap, keterampilan, dan pengetahuan. Para ilmuwan dalam melaksanakan kerja ilmiah lebih mengedepankan penalaran induktif (inductive reasoning) dibanding penalaran deduktif (deductive reasoning). Penalaran deduktif dilakukan dengan mengamati fenomena umum untuk menarik kesimpulan yang spesifik. Sebaliknya, penalaran induktif dilakukan dengan mengamati fenomena atau situasi spesifik untuk menarik kesimpulan secara keseluruhan.

Beberapa prinsip pendekatan ilmiah dalam kegiatan pembelajaran adalah pembelajaran yang berpusat pada anak didik, terhindar dari verbalisme, dapat membentuk students' self concept, memberikan kesempatan pada mahasiswa untuk mengasimilasi dan mengakomodasi konsep, hukum, dan prinsip, mendorong terjadinya peningkatan kemampuan berpikir mahasiswa, meningkatkan motivasi belajar mahasiswa dan mengajar guru, memberikan kesempatan kepada mahasiswa untuk melatih kemampuan dalam komunikasi, dan adanya proses validasi terhadap konsep, hukum, dan prinsip yang dikonstruksi siswa dalam struktur kognitifnya.

Pada pembelajaran ini diketahui bahwa pada tahapan terakhir, mahasiswa mampu mengelola hasil melalui proses belajar penemuan dan mengevaluasi kesimpulan yang telah dibuat (Veermans, 2013). Kegiatan mengevaluasi digunakan untuk memeriksa pemahaman yang telah dibuat oleh mahasiswa, sehingga pemahaman yang dimiliki oleh mahasiswa sesuai dengan konsep yang benar.

Adapun apabila pembelajaran berbasis Guided Discovery yang telah dilaksanakan dikaitkan dengan teori pembelajaran, berikut 
adalah pemaparannya. Teori Vygotsky menekankan pada aspek sosial pembelajaran karena ia yakin bahwa interaksi sosial dengan orang lain dapat memicu pembangunan ide-ide baru dan memperkaya perkembangan intelektual mahasiswa. Menurut Vygotsky, proses pembelajaran terjadi apabila mahasiswa bekerja atau mengerjakan tugas yang belum pernah dipelajari, namun tugas tersebut masih berada dalam daerah perkembangan mahasiswa atau yang disebut dengan zone of proximal development.

Ide penting dari Vygotsky adalah scaffolding, yaitu mahasiswa diberikan tugas yang sulit dan realistik, dan diberikan bantuan secukupnya dalam menyelesaikan tugas tersebut dengan tujuan memberikan kesempatan pada mahasiswa untuk mengambil alih tanggungjawab yang semakin besar segera setelah mahasiswa dapat melakukannya (Nur dkk., 2008b).

Selain itu, pembelajaran Guided discovery juga dapat dikaitkan dengan teori perkembangan kognitif. Teori pembelajaran ini menerangkan bahwa setiap individu harus membangun pengetahuan sendiri atau melalui pengalaman sendiri dengan lingkungannya. Menurut pandangan Piaget, pengetahuan datang dari tindakan, perkembangan kognitif, dan sebagian besarnya bergantung pada seberapa jauh anak aktif berinteraksi dengan lingkungannya. Prinsip Piaget ini dapat diterapkan dalam proses pembelajaran yang menekankan pada kegiatan penemuan, penyelidikan, dan pengalaman nyata agar mahasiswa dapat memperoleh pengalaman belajar yang luas (Nur dkk., 2008a).

Berdasarkan pemaparan terkait hasil penelitian yang telah diperoleh, dapat diasumsikan bahwa pembelajaran Guided discovery mampu meningkatkan kualitas belajar mahasiswa dibuktikan dari persepsi positif yang diberikan oleh mahasiswa. Sehingga perlu dilaksanakan pembelajaran ini pada materi yang lain dan pada mata kuliah yang lain agar sikap ilmiah, keterampilan, dan hasil belajar mahasiswa mampu meningkat secara signifikan.

\section{SIMPULAN}

Berdasarkan hasil penelitian yang telah diperoleh, dapat disimpulkan bahwa respons mahasiswa terhadap pembelajaran berbasis Guided discovery pada mata kuliah Anatomi dan Fisiologi Makhluk Hidup termasuk dalam kategori kuat, dengan persentase sebesar $75 \%$.

\section{DAFTAR PUSTAKA}

Akanmu, M.A., \& Fejenidagba. 2013. Guideddiscovery Learning Strategy and Senior School Students Performance in Mathematics in Ejigbo, Nigeria. Journal of Education and Practice, 4 (12): 82-89.

Akinbobola \& Afolabi. 2010. Constructivist practices through guided discovery approach: The effect on students' cognitive achievement in Nigerian senior secondary school physics. Eurasian Journal Physcal Chemistry Education, 2(1):16-25.

Ali, G. 2013. Studying the Effect of Guided Discovery Learning on Reinforcing The Creative Thingking of Sixth Grade Girl Student in Qom during 2012-2013 Academic Year. Journal of Applied Sciece and Agriculture, 8(5): 576-584.

Ali, G. 2013. Studying the Effect of Guided Discovery Learning on Reinforcing The Creative Thingking of Sixth Grade Girl Student in Qom during 2012-2013 Academic Year. Journal of Applied Sciece and Agriculture, 8(5): 576-584.

Badan Standar Nasional Pendidikan. 2012. Laporan Hasil Ujian Nasional SMP/MTs Tahun Pelajaran 2011/2012. Jakarta: Pusat Penilaian Pendidikan BALITBANG KEMENDIKBUD.

Bambang, S., dan Anwar, S. 2009. Pengembangan Model Pembelajaran Discovery Learning Ilmu Pendidikan untuk Meningkatkan Pemahaman Konsep Pendidikan Mahasiswa PGSD FIP UNY. Jurnal Penelitian Ilmu Pendidikan 2(1): 54.

Bonwell, C.C. 1998. Active Learning : Energizing The Class Room. Green Mountain Falls, Co : Active Learning Workshop.

Candra E.P., Sunyoto E.N., \& Wiyanto. 2012. Penerapan Model Pembelajaran Guided Discovery pada Materi Pamantulan Cahaya untuk Meningkatkan Berpikir Kritis. Unnes Physics Educational Journal, 1(1): 26-32.

Dahar, R.W. 2011. Teori-Teori Belajar dan Pembelajaran. Jakarta : Erlangga.

Destrini, H., Nirwana, \& Sakti, I. (2018). Penerapan Model Pembelajaran 


$\begin{array}{lrr}\text { Penemuan } & \text { Terbimbing } & \text { (Guided } \\ \text { Discovery } & \text { Learning) } & \text { untuk } \\ \text { Meningkatkan } & \text { Hasil Belajar dan } \\ \text { Keterampilan Proses Sains Siswa. } & \text { Pars } \\ \text { Kumparan Fisika, Vol.1, No.1, 18. }\end{array}$

Gholamian, A. 2013. Studying The Effect of Guided Discovery Learning on Reinforcing The Creative Thingking of Six Grade Girls Students in Qom During 2012-2013 Academic Year. Journal of Applied Science and Agriculture, 8(5): 576-584.

Hutami, D.P. \& Wiyatno, Y. (2018). Pengembangan Perangkat Pembelajaran Berbasis Guided Discovery Learning Untuk Meningkatkan Pemahaman Konsep Dan Kemampuan Kerja Sama Peserta Didik. Jurnal Pendidikan Fisika, Vol.7, No.1, 18.

Kyporus, Tarawneh, Vasquez, Knecht, \&Wrinkle. (2012). Lessons Learned Implementing and Optimizing Guided Discovery Modules. Proceedings Frontiers in Education Conference.hlm. 1-6. University of Texas-Pan American.

Lavine, R. A. (2005). Guided Discovery Learning with Videotaped Case Presentation in Neurobiology. Journal Medical Science Educator, 15(1), 4-7.

Leonard, Kalinowski, \& Andrew.(2014). Misconceptions Yesterday, Today, and Tomorrow.Proceedings Frontiers in Education Conference, FIE, 13(2), 179186.

Pamungkas, D. A. (2011). Peningkatan Motivasi dan Kedisiplinan Belajar Matematika topik Segiempat melalui Pembelajaran Guided Discovery (PenemuanTerbimbing) dengan Macromedia Flash pada Siswa Kelas VII SMP Negeri 2 Ngrampal Sragen. Kumpulan Abstrak Hasil Penelitian Universitas Negeri Yogyakarta, Hlm 7.LP UNY.

Pardede, E., Motlan, \& Suryanti, R.D. (2016). Efek Model Pembelajaran Guided Discovery Berbasis Kolaborasi Dengan Media Flash Terhadap Keterampilan Proses Sains Dan Hasil Belajar Kognitif Tinggi Fisika Siswa SMA. Jurnal Pendidikan Fisika, Vol.5, No.1, 06-16.
Qorri'ah. (2011). PenggunaanMetode Guided Discovery Learning untuk Meningkatkan Pemahaman KonsepSiswa pada Pokok Bahasan Bangun Ruang Sisi Lengkung. Kumpulan Abstrak Hasil Penelitian UIN Syarif Hidayatullah, Hlm 7. LP UIN Syarif HIdayatullah.

Rachayuni. (2016). Meningkatkan Keterampilan Proses Sains dan Hasil Belajar IPA melalui Penerapan Model Guided Discovery di Kelas VII-1 SMPN 32 Semarang. Jurnal Scientia Indonesia, 66-73.

Ratumanan. (2009). Model-model Pembelajaran. Jakarta Bumi: Aksara.

Reeves, T.C. (2006). How Do You Know They are Learning? The Importance of Alignment in Higher Education.International Journal of LearningTechnology, 2(4): 204-307.

Rustaman. (2005). Strategi Belajar Mengajar Biologi. Malang: UM press.

Shieh, C., \& Lean, Y. 2016. A Study on Information Technology Integrated Guided Discovery Instruction Towards Students' Learning Achievement and Learning Retention. Eurasia Journal of Mathematics, Science \& Technology Education, 12(4): 833-842.

Slavin, R. 2009. Psikologi pendidikan: Teori, Riset dan Praktek. Bandung : Nusa Media.

Taufik, W.D.S. 2012. Pengaruh Penerapan Model Pembelajaran Guided Discovery terhadap Kemampuan Berpikir Kreatif Siswa Kelas X SMA Negeri 1 Teras Boyolali Tahun Pelajaran 2011/2012. Skripsi FKIP Universitas Sebelas Maret Surakarta.

Yusniawati, R.P., Sajidan, \& Sugiyarto. 2015. Pengembangan dan Implementasi Model Pembelajaran Guided discovery dipadu dengan Numbered Head Together pada Materi Struktur Tumbuhan dan Pemanfaatannya dalam Teknologi di SMPN 4 Karanganyar. Jurnal Inkuiri, Vol.4, No.4, 15 